\title{
GHRH/HaeIII gene polymorphism and its associations with milk production traits in Polish Black-and-White cattle (short communication)
}

\begin{abstract}
The objective of this paper was to evaluate the relationship between the polymorphism of the GHRH and milk production traits of Polish Black-and-White. A total of 881 cows were included in the study. A PCR-RFLP method was used to genotyping. The frequencies of the genotypes and alleles were as follows: 0.0545 for $A A$, 0.3133 for $A B$ and 0.6322 for $B B$, and 0.2111 for $G H R H^{A}$ and $0.7889-G H R H^{B}$. There were no significant associations between GHRH/HaeIII polymorphism and milk production traits of the analysed cows.
\end{abstract}

Key Words: GHRH gene, PCR-RFLP, milk production traits, dairy cattle

\section{Zusammenfassung}

Titel der Arbeit: Polymorphismus des GHRH/HaeIII-Gens und sein Zusammenhang zwischen den Milchleistungsmerkmalen bei schwarzbunten Kühen (Kurzmitteilung)

Zusammenhänge zwischen dem Polymorphismus des GHRH-Gens wurden bei schwarzbunten Kühen analysiert. Die Untersuchungen wurden an 881 Kühen durchgeführt. Angewandt wurde die PCR-RFLP-Methode. Die Genotyp- und Allelfrequenz war wie folgt: für $A A 0.0545$, für $A B 0.3133$ und für $B B 0.6322$ sowie für $G H R H^{A}$ 0.2111 und 0.7889 für $\mathrm{GHRH}^{B}$. Zwischen dem Polymorphismus von GHRH/HaeIII-Gen und den Milchleistungsmerkmalen bei untersuchten Kühen wurden keine Zusammenhänge festgestellt.

Schlüsselwörter: GHRH-Gen, PCR-RFLP, Milchrind, Milchleistungsmerkmale

\section{Introduction}

Identification of the genes underlying livestock production traits (quantitative trait loci - QTL) is likely to lead to more efficient the traditional breeding programs and is a promising way to improve production traits of farm animals. Among the putative candidate genes, milk protein loci have been studied most extensively (PARMENTIER et al., 1999). Another group are genes related to the somatotropic axis (RENAVILLE et al., 1997; SØRENSEN et al., 2002; DYBUS et al., 2003, 2005). Growth hormone releasing hormone (GHRH) stimulates both synthesis and secretion of pituitary growth hormone (GH) binds to specific receptors on somatotrophs (FROHMAN et al., 1992). Bovine GHRH increased the serum concentration of endogenous GH (LØVENDAHL et al., 1991) and increased milk production (LAPIERRE et al., 1988). VANDERKOOI et al. (1995) reported that bGHRH stimulates milk synthesis through the same mechanisms as bGH. BESWICK and KENNELLY (1998), who measured mRNA and protein abundance of the acetyl-CoA carboxylase (ACC) and fatty acid synthase (FAS) in the mammary gland and adipose tissue, presented a potential role of GHRH in the lipid metabolism of the mammary gland. 
Bovine GHRH gene was linked to CSSM30 on chromosome 13 and represents U11 synteny group (BARENDSE et al., 1994). The bovine $G H R H$ gene consists of five exons separated by four introns (ZHOU et al., 2000).

In a preliminary study on 89 artificial insemination (AI) Holstein-Friesian bulls, MOODY et al. (1995) observed that the rare (7.7\%) $A A$ genotype, identified with PCR-RFLP HaeIII restriction enzyme improved both fat percentage and fat yield.

The aim of this study was to estimate the allelic frequencies at the GHRH-HaeIII locus and to investigate the relationship of this polymorphism and milk production traits of Polish Black-and-White cows.

\section{Materials and methods}

A total of 881 Black-and-White (B\&W) cows were genotyped. The GHRH-HaeIII genotypes were analysed using the PCR-RFLP method. Crude DNA was isolated from blood samples using MasterPure ${ }^{T M}$ kit (Epicentre Technologies). A 297-bp fragment of the GHRH gene was amplified using methodology of DYBUS et al. (2003). The following cycles were applied: initial denaturation, $94^{\circ} \mathrm{C} / 5 \mathrm{~min}$, followed by 30 cycles: denaturation, $94^{\circ} \mathrm{C} / 40 \mathrm{sec}$, primer annealing, $60^{\circ} \mathrm{C} / 40 \mathrm{sec}$, PCR products synthesis, $72^{\circ} \mathrm{C} / 40 \mathrm{sec}$, and final synthesis, $72^{\circ} \mathrm{C} / 5 \mathrm{~min}$. The amplified DNA was digested with 5 units of HaeIII enzyme (MBI Fermentas). The digestion products were separated by horizontal electrophoresis (90 volts, 50 minutes) through 3\% agarose gels (Prona) in 1 $\mathrm{x}$ TBE and $0.5 \mu \mathrm{M}$ ethidium bromide.

Data for 305-day milk production in the first, second and third lactation were obtained from farm records. Statistical calculations were performed using procedures of STATISTICA (2005). The effect of the GHRH/HaeIII genotypes on the milk production traits were analysed using a General Linear Model (GLM). The following statistical model was used:

$y_{i j k l m n o}=\mu+G_{i}+s_{j}+D_{k}+H_{l}+Y S_{m}+b_{1}\left(x_{n}-A_{n}\right)+b_{2}\left(x_{o}-H F_{o}\right)+e_{i j k l m n o}$

where:

$y_{i j k l m n o}$ - analyzed trait; $\mu$ - overall mean; $G_{i}$ - fixed effect of GHRH genotype $(i=1, \ldots 3) ; s_{j}-$ random effect of sire $\left(j=1, \ldots 175 / 147 / 103^{*}\right) ; D_{k}$ - fixed effect days of milk $(k=1,2) ; H_{l}-$ fixed effect of barns $(l=1, \ldots 5) ; Y S_{m}$ - fixed effect year-season $\left(m=1, \ldots 17 / 15 / 13^{*}\right) ; b_{1}$ - linear regression coefficient of calving age; $x_{n}$ - calving age in month of a cow $(n=1,2) ; A_{n}-$ mean calving age; $b_{2}$ - linear regression coefficient of percentage of HF genes; $x_{o}$-percentage of $H F$ genes in a cow $(0=1,2) ; H_{o}-$ mean percentage of $H F$ genes; $e_{i j k l m n o}$-random error

* - in the first/second/third lactation

\section{Results}

The following restriction fragments were obtained: 242 and 55 bp for the $A A$ genotype, 242, 194, 55, 48 for the $A B$ genotype, and 194, 55, 48 bp for the $B B$.

The table shows the influence of the GHRH-HaeIII polymorphism on milk production traits in the Black-and-White cows.

In the analysed population of $B \& W$ cattle, the $B B$ genotype was the most frequent (0.6322), followed by the $A B(0.3133)$, whereas the $A A$ was the least frequent (0.0545), respectively. The frequency of $G H R H^{A}$ estimated for analysed cattle was 0.2111. A higher frequency of the $G H R H^{A}(0.70)$ in Angus cattle, and lower $(0.07$ and 0.1) in Hereford and Limousine cattle (MOODY et al., 1995; DYBUS et al., 2003). 
Table

Means and standard deviations of milk production traits in Black-and-White cows carrying different $G H R H$ HaeIII genotypes (Mittelwerte und Standardabweichungen der Milchleistungsmerkmale bei Kühen mit verschiedenen Genotypen GHRH-HaeIII)

\begin{tabular}{|c|c|c|c|c|c|c|c|c|}
\hline Lactation & $\begin{array}{c}G H R H \\
\text { Genotype }\end{array}$ & $\mathrm{n}$ & $\begin{array}{l}\text { Milk yield } \\
\text { (kg) }\end{array}$ & $\begin{array}{l}\text { Fat } \\
(\mathrm{kg})\end{array}$ & $\begin{array}{l}\text { Fat } \\
(\%)\end{array}$ & $\begin{array}{l}\text { Protein } \\
\text { (kg) }\end{array}$ & $\begin{array}{l}\text { Protein } \\
\text { (\%) }\end{array}$ & $\begin{array}{l}\text { F\&P } \\
(\%)\end{array}$ \\
\hline \multirow{3}{*}{$1^{\text {st }}$} & $A A$ & 48 & $\begin{array}{c}5247 \\
(1648)\end{array}$ & $\begin{array}{c}224.3 \\
(77.25)\end{array}$ & $\begin{array}{c}4.24 \\
(0.45)\end{array}$ & $\begin{array}{c}166.3 \\
(54.80)\end{array}$ & $\begin{array}{c}3.16 \\
(0.19)\end{array}$ & $\begin{array}{c}7.40 \\
(0.57)\end{array}$ \\
\hline & $A B$ & 276 & $\begin{array}{c}5240 \\
(1252)\end{array}$ & $\begin{array}{c}217.9 \\
(55.05)\end{array}$ & $\begin{array}{c}4.16 \\
(0.41)\end{array}$ & $\begin{array}{c}165.3 \\
(42.85)\end{array}$ & $\begin{array}{c}3.14 \\
(0.21)\end{array}$ & $\begin{array}{c}7.30 \\
(0.53)\end{array}$ \\
\hline & $B B$ & 557 & $\begin{array}{c}5281 \\
(1382)\end{array}$ & $\begin{array}{c}217.4 \\
(62.74)\end{array}$ & $\begin{array}{c}4.11 \\
(0.44)\end{array}$ & $\begin{array}{c}167.2 \\
(46.49)\end{array}$ & $\begin{array}{c}3.16 \\
(0.19)\end{array}$ & $\begin{array}{c}7.28 \\
(0.55)\end{array}$ \\
\hline \multicolumn{2}{|c|}{ Total } & 881 & $\begin{array}{c}5267 \\
(1358)\end{array}$ & $\begin{array}{c}218.0 \\
(61.28)\end{array}$ & $\begin{array}{c}4.14 \\
(0.43)\end{array}$ & $\begin{array}{c}166.5 \\
(45.83)\end{array}$ & $\begin{array}{c}3.16 \\
(0.19)\end{array}$ & $\begin{array}{c}7.29 \\
(0.54)\end{array}$ \\
\hline \multicolumn{3}{|c|}{ F value (genotype effect) } & 0.21 & 0.09 & 0.19 & 0.43 & 1.04 & 0.19 \\
\hline \multirow{3}{*}{$2^{\text {nd }}$} & $A A$ & 35 & $\begin{array}{c}5784 \\
(1542)\end{array}$ & $\begin{array}{c}262.9 \\
(78.52)\end{array}$ & $\begin{array}{c}4.53 \\
(0.61)\end{array}$ & $\begin{array}{c}185.8 \\
(53.56)\end{array}$ & $\begin{array}{c}3.20 \\
(0.23)\end{array}$ & $\begin{array}{c}7.74 \\
(0.71)\end{array}$ \\
\hline & $A B$ & 176 & $\begin{array}{c}5758 \\
(1195)\end{array}$ & $\begin{array}{c}244.9 \\
(57.07)\end{array}$ & $\begin{array}{c}4.26 \\
(0.45)\end{array}$ & $\begin{array}{c}185.2 \\
(41.92)\end{array}$ & $\begin{array}{c}3.20 \\
(0.23)\end{array}$ & $\begin{array}{c}7.46 \\
(0.55)\end{array}$ \\
\hline & $B B$ & 368 & $\begin{array}{c}5732 \\
(1310)\end{array}$ & $\begin{array}{c}235.0 \\
(63.66)\end{array}$ & $\begin{array}{c}4.09 \\
(0.52)\end{array}$ & $\begin{array}{c}186.1 \\
(46.02)\end{array}$ & $\begin{array}{c}3.23 \\
(0.21)\end{array}$ & $\begin{array}{c}7.32 \\
(0.61)\end{array}$ \\
\hline \multicolumn{2}{|c|}{ Total } & 579 & $\begin{array}{c}5743 \\
(1289)\end{array}$ & $\begin{array}{c}239.7 \\
(63.06)\end{array}$ & $\begin{array}{c}4.16 \\
(0.52)\end{array}$ & $\begin{array}{c}185.8 \\
(45.23)\end{array}$ & $\begin{array}{c}3.22 \\
(0.22)\end{array}$ & $\begin{array}{c}7.39 \\
(0.61)\end{array}$ \\
\hline \multicolumn{3}{|c|}{ F value (genotype effect) } & 0.39 & 0.25 & 1.87 & 0.15 & 0.98 & 1.66 \\
\hline \multirow{3}{*}{$3^{\text {rd }}$} & $A A$ & 20 & $\begin{array}{c}6322 \\
(1167)\end{array}$ & $\begin{array}{c}286.7 \\
(59.55)\end{array}$ & $\begin{array}{c}4.54 \\
(0.47)\end{array}$ & $\begin{array}{c}196.0 \\
(38.86)\end{array}$ & $\begin{array}{c}3.10 \\
(0.20)\end{array}$ & $\begin{array}{c}7.64 \\
(0.55)\end{array}$ \\
\hline & $A B$ & 115 & $\begin{array}{c}6238 \\
(1421)\end{array}$ & $\begin{array}{c}263.3 \\
(69.88)\end{array}$ & $\begin{array}{c}4.21 \\
(0.56)\end{array}$ & $\begin{array}{c}199.4 \\
(47.46)\end{array}$ & $\begin{array}{c}3.17 \\
(0.21)\end{array}$ & $\begin{array}{c}7.38 \\
(0.66)\end{array}$ \\
\hline & $B B$ & 213 & $\begin{array}{c}6029 \\
(1353)\end{array}$ & $\begin{array}{c}244.0 \\
(68.58)\end{array}$ & $\begin{array}{c}4.02 \\
(0.52)\end{array}$ & $\begin{array}{c}194.3 \\
(46.23)\end{array}$ & $\begin{array}{c}3.21 \\
(0.18)\end{array}$ & $\begin{array}{c}7.23 \\
(0.60)\end{array}$ \\
\hline \multicolumn{2}{|c|}{ Total } & 348 & $\begin{array}{c}6115 \\
(1367)\end{array}$ & $\begin{array}{c}252.9 \\
(69.44)\end{array}$ & $\begin{array}{c}4.11 \\
(0.54)\end{array}$ & $\begin{array}{c}196.1 \\
(46.20)\end{array}$ & $\begin{array}{c}3.19 \\
(0.19)\end{array}$ & $\begin{array}{c}7.30 \\
(0.63)\end{array}$ \\
\hline \multicolumn{3}{|c|}{ F value (genotype effect) } & 0.21 & 0.22 & 1.02 & 0.32 & 2.19 & 1.03 \\
\hline
\end{tabular}

Discussion

A number of strategies can be envisaged to identify candidate gene markers. One of them uses a candidate gene approach. This strategy consists of the study of mutations/polymorphisms of different genes potentially involved in a physiological process. Various authors have found QTLs for different traits of cattle and linked them to numerous chromosome regions (HEYEN et al., 1999; KUHN et al., 2003). SCHROOTEN et al. (2000) reported a QTL influencing fore udder attachment near the TGLA23 marker on BTA13. The authors indicate that quantitative trait loci for udder traits on chromosomes 13 may also affect somatic cell score and mastitis resistance. On BTA13, ASHWELL et al. (2001) detected a QTL for canonical conformation traits. In the other study, HIENDLEDER et al. (2003) performed a whole genome scan in a granddaughter design and detect QTL on chromosome 13 affecting teat length. 
It is interesting where the region of $\mathrm{GHRH} / \mathrm{Hae}$ III mutation is located, especially since the rare $A A$ genotype of $G H R H$ was significantly favourable for fat percentage (MOODY et al., 1995). These authors located the polymorphism in the exon 3 of GHRH comparing the sequence of the amplified fragment (GenBank, U29611) with an analogical sequence in the human (homology 91\%) and murine (77\%) GHRH gene. If we compare the sequence published by MOODY et al. (1995) with the complete GHRH sequence (AF242855 - GenBank 2000), it turns out that the fragment amplified by the authors does not correspond to exon 3, but it covers a part of exon 2, the entire intron 2, and a part of exon 3; the analysed polymorphic site is located in intron 2.

Our experiment din not confirms the associations found by MOODY et al. (1995). No associations between RFLP in GHRH gene and milk production traits were found. The lack of significant differences between the particular GHRH genotypes was a result of both the effect of the selected factors on the studied traits and the covariates used in the model. However, the results obtained in the study indicate that cows with one or two $G H R H^{A}$ alleles could yield more fat in their milk. It should be verified in further studies with the more balanced populations of dairy cattle.

\section{Acknowledgments}

This study was supported by a grant no. P06D00719 from the Polish State Committee for Scientific Research. The first author would like to thank to Professor MAREK KMIEĆ for help and inestimable advices during and after realization of this study.

\section{References}

ASHWELL, M.S.; HEYEN, D.W.; SONSTEGARD, T.S.; VAN TASSELL, C.P.; DA, Y.; VANRADEN, P.M.; RON, M.; WELLER, J.I.; LEWIN, H.A.:

Detection of quantitative trait loci affecting milk production, health, and reproductive traits in Holstein cattle. J. Dairy Sci. 87 (2004), 468-475

ASHWELL, M.S.; VAN TASSELL, C.P.; SONSTEGARD, T.S.:

A genome scan to identify quantitative trait loci affecting economically important traits in a US Holstein population. J. Dairy Sci. 84 (2001), 2535-2542

BARENDSE, W.; ARMITAGE, S.M.; KOSSAREK, L.M.; SHALOM, A.; KIRKPATRICK, B.W.; RYAN, A.M.; CLAYTONI, D.; LI, L.; NEIBERGS, H.L.; ZHANG, N.; GROSSE , W.M.; WEISS, J.; CREIGHTON, P.; MCCARTHY, F.; RON, M.; TEALE, A.J.; FRIES, R.; MCGRAW, R.A.; MOORE, S.S.; GEORGES, M.; SOLLER, M.; WOMACK, J.E.; HETZEL, D.J.S.:

A genetic linkage map of the bovine genome. Nat. Genet. 6 (1994), 227-235

BESWICK, N.S.; KENNELLY, J.J.:

The influence of bovine growth hormone and growth hormone releasing factor on acetyl-CoA carboxylase and fatty acid synthase in primiparous Holstein cows. Comp. Biochem. Physiol. C Pharmacol. Toxicol. Endocrinol. 120 (1998), 241-249

BLOTT, S.; KIM, J.-J.; MOISIO, S.; SCHMIDT-KÜNTZEL, A.; CORNET, A.; BERZI, P.; CAMBISANO, N.; FORD, C.; GRISART, B.; JOHNSON, D.; KARIM, L.; SIMON, P.; SNELL, R.; SPELMAN, R.; WONG, J.; VILKKI, J.; GEORGES, M.; FARNIR, F.; COPPIETERS, W.:

Molecular dissection of a quantitative trait locus: A phenylalanine-to-tyrosine substitution in the transmembrane domain of the bovine growth hormone receptor is associated with a major effect on milk yield and composition. Genetics 163 (2003), 253-266

DYBUS, A.; GRZESIAK, W.; KAMIENIECKI, H.; SZATKOWSKA, I.; SOBEK, Z.; BŁASZCZYK, P.; CZERNIAWSKA-PIĄTKOWSKA, E.; ZYCH, S.; MUSZYŃSKA, M.:

Association of genetic variants of bovine prolactin with milk production traits of Black-and-White and Jersey cattle. Arch. Tierz., Dummerstorf 48 (2005), 149-156

DYBUS, A.; KMIEĆ, M.; SOBEK, Z.; PIETRZYK, W.; WIŚNIEWSKI, B.:

Associations between polymorphisms of growth hormone releasing hormone (GHRH) and pituitary transcription factor 1 (PIT1) genes and production traits of limousine cattle. Arch. Tierz., Dummerstorf 46 (2003), 527-534

FROHMAN, L.A.; BOWNS, T.R.; CHOMCZYNSKI, P.: 
Regulation of growth hormone secretion. Front. Neuroendocrinol. 13 (1992), 344-405

GRISART, B.; COPPIETERS, W.; FARNIR, F.; KARIM, L.; FORD, C.; BERZI, P.; CAMBISANO, N.; MNI, M.; REID, S.; SIMON, P.; SPELMAN, R.; GEORGES, M.; SNELL, R.:

Positional candidate cloning of a QTL in dairy cattle: Identification of a missense mutation in the bovine DGAT1 gene with major effect on milk yield and composition. Genome Res. 12 (2002), 222231

HIENDLEDER, S.; THOMSEN, H.; REINSCH, N.; BENNEWITZ, J.; LEYHE-HORN, B.; LOOFT, C.; XU, N.; MEDJUGORAC, I.; RUSS, I.; KÜHN, C.; BROCKMANN, G.A.; BLÜMEL, J.; BRENIG, B.; REINHARDT, F.; REENTS, R.; AVERDUNK, G.; SCHWERIN, M.; FÖRSTER, M.; KALM, E.; ERHARDT, G.:

Mapping of QTL for Body Conformation and Behavior in Cattle. J. Hered. 94 (2003), 496-506

HEYEN, D.W.; WELLER, J.I.; RON, M.; BAND, M.; BEEVER, J.E.; FELDMESSER, E.; DA, Y.; WIGGANS, G.R.; VANRADEN, P.M.; LEWIN, H.A.:

A genome scan for QTL influencing milk production and health traits in dairy cattle. Physiol. Genomics 1 (1999), 165-175

KUHN, C.H.; BENNEWITZ, J.; REINSCH, N.; XU, N.; THOMSEN, H.; LOOFT, C.; BROCKMANN, G.A.; SCHWERIN, M.; WEIMANN, C.; HIENDLEDER, S.; ERHARDT, G.; MEDJUGORAC, I.; FORSTER, M.; BRENIG, B.; REINHARDT, F.; REENTS, R.; RUSS, I.; AVERDUNK, G.; BLUMEL, J.; KALM, E.: Quantitative trait loci mapping of functional traits in the German Holstein cattle population. J. Dairy Sci. 86 (2003), 360-368

LAPIERRE, H. ; PELleTier, G. ; PETIClERC, D. ; DUBREUIL, P. ; MORISSET, J.; GAUDREAU, P. ; COUTURE, Y. ; BRAZEAU, P.: Effect of human growth hormone-releasing factor (1-29) $\mathrm{NH}_{2}$ on growth hormone release and milk production in dairy cows. J. Dairy Sci. 71 (1988), 92-98

LØVENDAHL, P.; WOOLLIAMS, J.A.; SINNETT-SMITH, P.A.: Response of growth hormone to various doses of growth hormone releasing factor and thyrotropin releasing hormone administered separately and in combination to dairy calves. Can. J. Anim. Sci. 71 (1991), 1045-1052

MOODY, D.E.; POMP, D.; BARENDSE, W.:

Restriction fragment length polymorphism in amplification products of the bovine growth hormonereleasing hormone gene. J. Anim. Sci. 73 (1995), 3789

PARMENTIER, I.; PORTETELlE, D.; GENGLER, N.; PRANDI, A.; BERTOZZI, C.; VLEURICK, L.; GILSON, R.; RENAVILLE, R.:

Candidate gene markers associated with somatotropic axis and milk selection. Domest. Anim. Endocrinol. 17 (1999), 139-148

RENAVILLE, R.; GENGLER, N.; VRECH, A.; PRANDI, A.; MASSART, S.; CORRADINI, C.; BERTOZZI, C.; MORTIAUX, F.; BURNY, A.; PORTETELLE, D.:

Pit-1 gene polymorphism, milk yield, and conformation traits for Italian Holstein-Friesian bulls. J. Dairy Sci. 80 (1997), 3431-3438

SCHROOTEN, C.; BOVENHUIS, H.; COPPIETERS, W.; VAN ARENDONK, J.A.: Whole genome scan to detect quantitative trait loci for conformation and functional traits in dairy cattle. J. Dairy Sci. 83 (2000), 795-806

STATSOFT, INC.: STATISTICA (data analysis software system), (2005) version 7.1. www.statsoft.com.

SØRENSEN, P.; GROCHOWSKA, R.; HOLM, L.; HENRYON, M.; LØVENDAHL, P.: Polymorphism in the Bovine Growth Hormone Gene Affects Endocrine Release in Dairy Calves. J. Dairy Sci. 85 (2002), 1887-1893

VANDERKOOI, W.K.; VANDEHAAR, M.J.; SHARMA, B.K.; BINELLI, M.; TUCKER, H.A.; AKERS, R.M.; MOSELEY, W.M.: Comparison of growth hormone-releasing factor and somatotropin: the somatotropic axis in lactating primiparous cows. J. Dairy Sci. 78 (1995), 2140-2149

ZHOU, P.; KAZMER, G.W.; YANG, X.:

Bos taurus growth hormone releasing hormone gene, complete cds. GenBank, AF 242855, (2000)

Received: 2005-11-01

Accepted: 2006-05-24

Corresponding Author

ANDRZEJ DYBUS, PhD

Agriculture University, Laboratory of Molecular Cytogenetics,

Doktora Judyma 12,

71-460 SZCZECIN, POLAND

E-Mail: andrzej.dybus@biot.ar.szczecin.pl 